\title{
Isolation of $\mathbf{H}$-protein loaded with methylamine as a transient species in glycine decarboxylase reactions
}

\author{
Michel NEUBURGER, Agnes JOURDAIN and Roland DOUCE \\ Laboratoire de Physiologie Cellulaire Végétale (Unité Associée au Centre National de la Recherche Scientifique $\mathrm{N}^{\circ} 576$ ), \\ Département de Biologie Moléculaire et Structurale, Centre d'Etudes Nucléaires et Université Joseph Fourier, \\ 85 X, F-38041 Grenoble-Cédex, France
}

\begin{abstract}
A three-step protocol was devised to purify $\mathrm{H}$-protein, which can be readily released as a soluble protein from pea mitochondria. After the final step of purification (anion-exchange chromatography) the native enzyme was eluted as two distinct peaks at 250 and $350 \mathrm{mM}-\mathrm{KCl}$ if the lysis buffer contained glycine. Each form exhibited an identical $M_{\mathrm{r}}$ of 15000 on SDS/PAGE and they were not distinguishable by PAGE under non-denaturating conditions. Both forms catalysed the rapid fixation of $\left[{ }^{14} \mathrm{C}\right]$ bicarbonate to the carboxy group atom of glycine during the exchange reaction, whereas the reversible exchange of electrons between NADH and lipoamide bound to the H-protein in the presence of 5,5'-dithiobis(2-nitrobenzoic acid) was seen only with the form eluted at $350 \mathrm{~mm}-\mathrm{KCl}$. During the early steps of $\mathrm{H}$-protein isolation, when $\mathrm{P}$ - and $\mathrm{H}$-protein react together in the presence of glycine, the methylamine intermediate bound to the lipoamide of the H-protein accumulates in the medium at the expense of oxidized H-protein. Under these conditions the methylamine intermediate, which is a rather stable structure, was easily separated from the oxidized H-protein on ionexchange chromatography. The methylamine bound to the lipoamide of the H-protein prevented the reversible exchange of electrons between NADH and lipoamide. High concentrations of glycine were required for the loading of $\mathrm{H}$-protein with methylamine catalysed by a large excess of P-protein.
\end{abstract}

\section{INTRODUCTION}

During the course of the oxidative photosynthetic carbon cycle or $\mathrm{C}_{2}$ cycle, glycine molecules formed in the peroxisomes are entirely broken down by a complex of proteins localized in the mitochondrial matrix which collectively catalyses the oxidative decarboxylation and deamination of glycine to form $\mathrm{CO}_{2}$, $\mathrm{NH}_{3}$ and $N^{5} N^{10}$-methylene-5,6,7,8-tetrahydropteroyl-L-glutamic acid (5,10- $\mathrm{CH}_{2} \mathrm{H}_{4}$ PteGlu) (Husic et al., 1987; Douce \& Neuburger, 1989). This reaction is too complex for a single enzyme and is catalysed by four different protein components referred to as the P-, H-, T-, and L-proteins (glycine cleavage) (Kikuchi \& Hiraga, 1982) (Scheme 1). The glycine decarboxylase complex has recently been isolated in an active form from pea mitochondria (Neuburger et al., 1986; Walker \& Oliver, 1986; Bourguignon et al., 1988).

Although substantial progress has been made in understanding the biochemistry of the glycine-cleavage complex from bacteria (Klein \& Sagers, 1966) and mammalian liver (Kikuchi \& Hiraga, 1982), little is known about the interactions between the Hprotein and the other proteins of the glycine-cleavage complex from leaf tissues (Walker \& Oliver, 1986; Bourguignon et al., 1988). We describe here a series of experiments designed to elucidate the function of the lipoamide-containing $\mathrm{H}$-protein in the whole sequence of reactions catalysed by the glycine-cleavage complex in mitochondria from green leaf tissues. Our results shed new light on the loading of the H-protein with the methylamine group derived from glycine decarboxylation and on the stability of the methylamine intermediate bound to the lipoamide of the H-protein.

\section{EXPERIMENTAL}

\section{Materials}

Pea (Pisum sativum L., var. 'Douce Provence') plants were grown from seeds in vermiculite for 15 days under a $12 \mathrm{~h}$ photoperiod of warm white light from fluorescent tubes $\left(20-40 \mu \mathrm{E} / \mathrm{m}^{2}\right.$ per s) at $28^{\circ} \mathrm{C}$. The plants can be grown at high density (20-30 plants $\left./ 100 \mathrm{~cm}^{2}\right)$. The plants were watered every day with tap water. Approximately $4-5 \mathrm{~kg}$ of fully expanded leaves were used for the isolation of mitochondria.

Mitochondria from pea leaves were prepared and purified by isopycnic centrifugation in density gradients of Percoll, as previously described (Douce et al., 1987).

5,6,7,8-Tetrahydropteroylglutamic acid $\left(\mathrm{H}_{4}\right.$ PteGlu) was prepared chemically by the catalytic hydrogenation of L-pteroylglutamic acid (Sigma) according to the method of Huennekens et al. (1963). The P-, T- and L-proteins were isolated from pea mitochondrial matrix according to Bourguignon et al. (1988).

\section{Methods}

Purification of H-protein. Pea leaf mitochondria (about $100 \mathrm{mg}$ of protein) were diluted in $100 \mathrm{ml}$ of lysis buffer containing 5 mM-Mops, 5 mM-Tris, $1 \mathrm{~mm}$-2-mercaptoethanol, 1 mM-EGTA, $20 \mu \mathrm{M}$-pyridoxal phosphate, $1 \mathrm{~mm}$-glycine and $1 \mathrm{~mm}$-octyl- $\beta$-Dglucopyranoside (Calbiochem), $\mathrm{pH}$ 7.0. Total release of the matrix protein was achieved by three cycles of freezing and thawing (Neuburger et al., 1986). The high- $M_{\mathrm{r}}$ complexes (above 300000 ) from the matrix fraction (matrix extract), containing all the proteins involved in the conversion of glycine into serine, were obtained according to Bourguignon et al. (1988). The matrix extract supplemented with $4 \mu \mathrm{M}$-leupeptin was applied to a column $(2.5 \mathrm{~cm} \times 35 \mathrm{~cm})$ of Sephacryl S-300 (Superfine grade; Pharmacia) equilibrated in $50 \mathrm{~mm}-\mathrm{KCl} /$ 5 mM-Mops / 5 mM-Tris (pH 7.5)/2 mM-2-mercaptoethanol / 1 mM-EGTA/1 mM-glycine (buffer A). The column connected to a Pharmacia f.p.l.c. system was eluted with the same buffer at $4^{\circ} \mathrm{C}$ (flow rate $0.5 \mathrm{ml} / \mathrm{min}$; fraction size $2 \mathrm{ml}$ ). $\mathrm{T}$ - and $\mathrm{H}$-protein were eluted together (light fraction). Pooled fractions containing

Abbreviations used: 5,10- $\mathrm{CH}_{2} \mathrm{H}_{4}$ PteGlu, $N^{5} N^{10}$-methylene-5,6,7,8-tetrahydropteroyl-L-glutamic acid; $\mathrm{H}_{4}$ PteGlu, 5,6,7,8-tetrahydropteroyl-Lglutamic acid; DTNB, 5,5'-dithiobis-(2-nitrobenzoic acid); TNB, 2-nitro-5-thiobenzoate. 


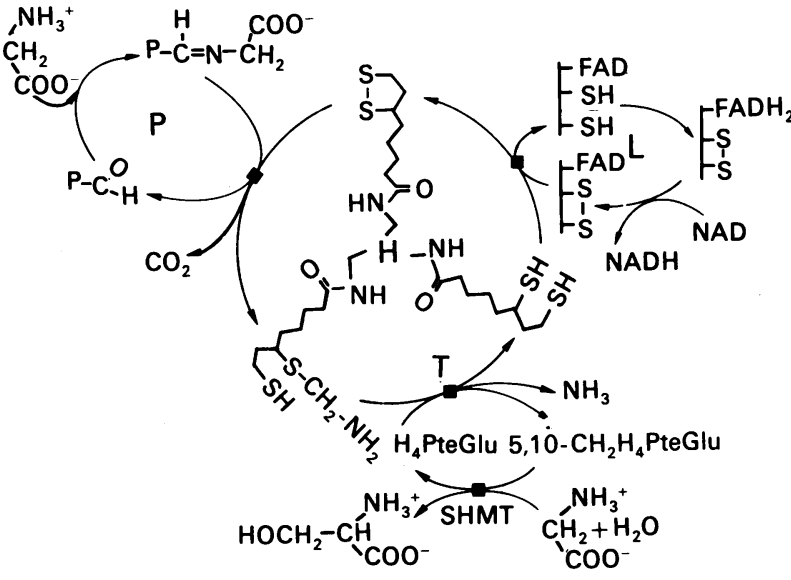

Scheme 1. Outline of the reactions involved in oxidative decarboxylation and deamination of glycine in plant mitochondrial matrix

$\mathrm{P}, \mathrm{H}, \mathrm{T}$ and $\mathrm{L}$ are the protein components of the glycine-cleavage system. The first step involves attack on the $\alpha$-amino group of glycine by a pyridoxal phosphate coenzyme bound to the P-protein forming a Schiff base with the $\alpha$-amino group of glycine at the active site of the P-protein. This component enzyme has an $M_{\mathrm{r}}$ of approximately 200000 and is a homodimer of $100 \mathrm{kDa}$ polypeptides. The pivotal enzyme in the whole sequence of reactions is the $15 \mathrm{kDa}$ lipoamide-containing H-protein. The lipoyl moiety in the H-protein is attached by an amide linkage to the $\epsilon$-amino group of a lysine residue (lysine-63 in the polypeptide chain) (Macherel et al., 1990). This linkage provides a flexible arm, about $1.4 \mathrm{~nm}(14 \AA ̊ \AA)$ in length, conceivably permitting the lipoyl moiety to swing among the active sites of the P-, T- and L-proteins. First the lipoamide group in its oxidized form interacts with the glycine-loaded P-protein: the glycine is oxidatively decarboxylated with the loss of the $\alpha$-carbon as $\mathbf{C O}_{2}$, the lipoamide moiety is reduced, and the remaining methylamine group of the glycine is passed to the lipoamide SH group. The Tprotein (a $45 \mathrm{kDa}$ monomer) catalyses the transfer of the carbon of the aminomethyl moiety from the lipoic acid to $\mathrm{H}_{4}$ PteGlu to form $5,10-\mathrm{CH}_{2} \mathrm{H}_{4}$ PteGlu, and $\mathrm{NH}_{3}$ is released. The reduced lipoamide, resulting from this transfer, is reoxidized back to lipoamide by the FAD coenzyme bound to the dihydrolipoyl dehydrogenase enzyme (L-protein, a homodimer of $60 \mathrm{kDa}$ polypeptides) with the sequential reduction of FAD and NAD ${ }^{+}$(Oliver et al., 1991). SHMT, serine hydroxymethyltransferase involved in the recycling of 5,10$\mathrm{CH}_{2} \mathrm{H}_{4}$ PteGlu to $\mathrm{H}_{4}$ PteGlu (Bourguignon et al., 1988).

$\mathrm{H}$-protein activity were dialysed and concentrated to $1-2 \mathrm{ml}$ by ultrafiltration (PM 10 membrane; Amicon) in $5 \mathrm{mM}$-Mops/ $5 \mathrm{~mm}$-Tris (pH 7.5)/2 mM-2-mercaptoethanol / $1 \mathrm{mm-EGTA}$ (buffer D). The pooled fractions of $\mathrm{H}$-protein were then applied to a Mono Q HR 10/10 column previously equilibrated in buffer D. H-protein was eluted at $4{ }^{\circ} \mathrm{C}$ and at $\mathrm{pH} 7.5$ with a continuously increasing $\mathrm{KCl}$ gradient $(0-500 \mathrm{~mm})$ in buffer $\mathrm{D}$ (flow rate $0.5 \mathrm{ml} / \mathrm{min}$; fraction size $1 \mathrm{ml}$ ). T-protein, which is positively charged at physiological $\mathrm{pH}$, was eluted in the void volume (see Bourguignon et al., 1988); by contrast, H-protein emerged as one or two peaks at approximately $180-350 \mathrm{mM}-\mathrm{KCl}$ (see the Results section). Purified H-protein fractions concentrated to $0.5 \mathrm{ml}$ by use of ultrafiltration on a YM-10 Amicon membrane were stored at $-80^{\circ} \mathrm{C}$ in buffer $\mathrm{D}$.

Loading of $\mathbf{H}$-protein with methylamine. The assay mixture, in a final volume of $100 \mu \mathrm{l}$, contained $20 \mathrm{mM}$-potassium phosphate, $\mathrm{pH} 7.4,5 \mu \mathrm{M}$-pyridoxal phosphate, $20 \mathrm{~mm}$-glycine, $30 \mu \mathrm{g}$ of Pprotein and $30 \mu \mathrm{g}$ of $\mathrm{H}$-protein. After $5 \mathrm{~min}$, portions were taken for $\mathrm{H}$-protein assay (see below) and purification of $\mathrm{H}$-protein to apparent homogeneity using ion-exchange f.p.l.c. (Bourguignon et al., 1988). We have verified that for a given glycine concentration, the final extent of loading wras attained in less than $2 \mathrm{~min}$.

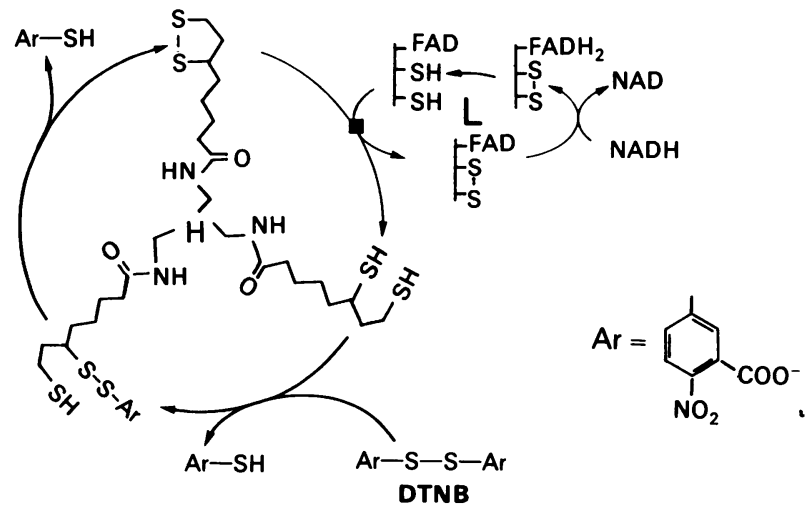

Scheme 2. Outline of the reactions involved in the reversible exchange of electrons between NADH and lipoamide bound to the H-protein

In the presence of NADH the L-protein catalyses the conversion of the disulphide bond of lipoamide into the SH groups. A large excess of DTNB catalyses back via intramolecular reactions the rapid conversion of the $\mathrm{SH}$ groups of lipoamide into the disulphide bond. Under these conditions the rate of formation of coloured 2-nitro-5thiobenzoate (Ar-SH), which is followed spectrophotometrically at $412 \mathrm{~nm}$ is directly proportional to the amount of $\mathrm{H}$-protein present in the assay medium.

Assay of H-protein. This reaction depends on the reversible exchange of electrons between NADH and lipoamide bound to the H-protein (Motokawa \& Kikuchi, 1969; Oliver et al., 1990). The reaction medium contained $0.1 \mathrm{~m}$-potassium phosphate (pH 7.4), 20 mM-EDTA, $10 \mu \mathrm{g}$ of pea lipoamide dehydrogenase, 2 mM-5,5'-dithiobis-(2-nitrobenzoic acid) (DTNB) and $2 \mathrm{~mm}$ $\mathrm{NADH}$ in a final volume of $0.6 \mathrm{ml}$. The reaction was initiated by the addition of the equivalent of up to $15 \mu \mathrm{g}$ of purified $\mathrm{H}$ protein. After a $20 \mathrm{~s}$ wait to allow for any reaction with the 2-mercaptoethanol in the purified enzyme preparation ( $L$ - and $\mathrm{H}$-protein), the reaction, leading to the formation of coloured 2-nitro-5-thiobenzoate (TNB), was followed spectrophotometrically at $412 \mathrm{~nm}$ [maximum absorbance of TNB $\left.\left(\epsilon_{\max }\right) 13.6 \times 10^{3} \mathrm{M}^{-1} \cdot \mathrm{cm}^{-1}\right]$. The reaction was linear for at least $5 \mathrm{~min}$ and the reaction rate was directly proportional to the amount of added H-protein. The mechanism involved in such interchange reactions is shown in Scheme 2, and $\mathrm{H}$-protein activity was expressed as $\mu \mathrm{mol}$ of TNB formed $/ \mathrm{min}$.

The activity of $\mathrm{H}$-protein was also determined by measuring the amounts of $\left[{ }^{14} \mathrm{C}\right]$ bicarbonate fixed to the carboxy group carbon atom of glycine during the exchange reaction (Hiraga \& Kikuchi, 1980). The assay mixture, in a final volume of $200 \mu \mathrm{l}$, contained $25 \mathrm{~mm}$-potassium phosphate, pH 7.0, $1 \mathrm{~mm}$ dithiothreitol, $20 \mu \mathrm{M}$-pyridoxal phosphate, $25 \mathrm{~mm}$-glycine, $40 \mathrm{~mm}-\left[{ }^{14} \mathrm{C}\right]$ bicarbonate, $30 \mu \mathrm{g}$ of P-protein and an appropriate amount of $\mathrm{H}$-protein to be tested. The reaction was initiated by addition of bicarbonate. At 5 and $10 \mathrm{~min}$ of incubation, a portion $(100 \mu \mathrm{l})$ of the reaction mixture was transferred to a glass radioactivity-counting vial containing $80 \mu \mathrm{l}$ of acetic acid, and the mixture was dried on a hot plate. The radioactivity was determined with an Intertechnique SL 4000 spectrometer after addition of $10 \mathrm{ml}$ of aqueous counting scintillant.

Electrophoretic analyses of $\mathbf{H}$-protein. The electrophoresis was performed at room temperature in SDS/polyacrylamide slab gels containing a $7.5-15 \%$ linear acrylamide gradient. The experimental conditions for gel preparation, sample solubilization, electrophoresis and gel staining are detailed by Chua (1980).

H-protein was also transferred electrophoretically to nitrocellulose (Bio-Rad) sheets essentially according to Towbin et al. (1979), using a trans-blot cell system (Bio-Rad). The electro- 


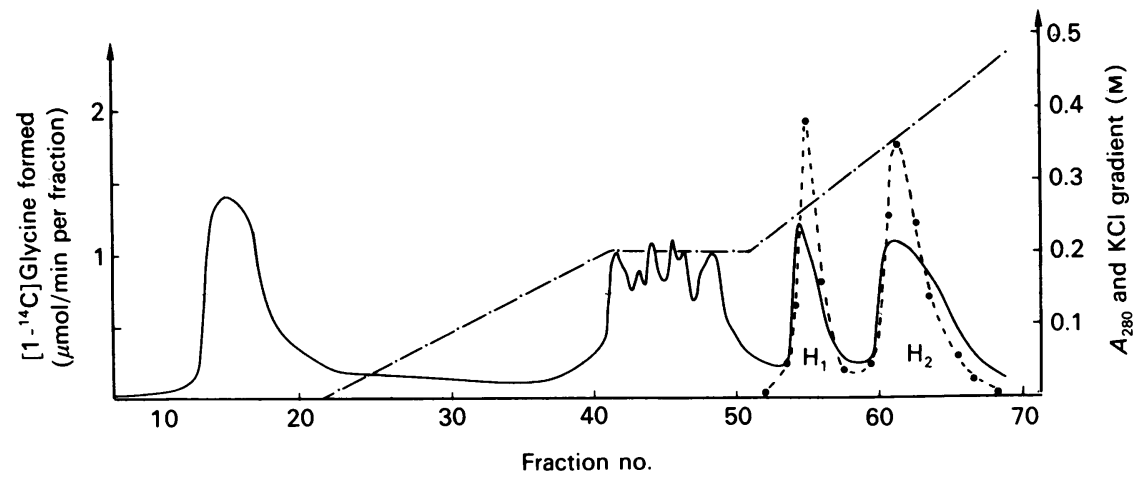

Fig. 1. Separation of $\mathbf{H}$-protein from pea leaf mitochondria by chromatography on Mono $\mathbf{Q}$

The preparation of H-protein from the matrix extract containing $2 \mathrm{mM}$-glycine was described in the text. Matrix extract was fractionated by gel filtration on Sephacryl S-300 (see the Experimental section) and the pooled fraction containing H-protein was applied to a Mono Q HR 10/10 column equilibrated in buffer D (see the Experimental section). After sample loading the column was eluted with a gradient of $0-0.5 \mathrm{M}-\mathrm{KCl}$ in buffer $\mathrm{D}(\cdot-\cdot-)$. Fractions of $1 \mathrm{ml}$ were collected and assayed for glycine- ${ }^{14} \mathrm{CO}_{2}$ exchange reaction $(0)$ (see the Experimental section). Note that the $\mathrm{H}$-protein was eluted as two distinct peaks $\left(\mathrm{H}_{1}\right.$ and $\left.\mathrm{H}_{2}\right)$ at 250 and $350 \mathrm{mM}-\mathrm{KCl}$ respectively.,$- A_{280}$.

phoresis was performed at room temperature in the following buffer: $25 \mathrm{~mm}$-Tris/192 mM-glycine $/ 20 \%$ (v/v) methanol, $\mathrm{pH} 8.3$; the power range was $60 \mathrm{~V}, 0.22 \mathrm{~A}$. The transfer was complete after about $3 \mathrm{~h}$. The sheets were then used for immunoblotting experiments.

Immunoblotting studies of $\mathbf{H}$-protein. We used polyclonal antibodies raised against H-protein (Macherel et al., 1990). Immunoblotting experiments were performed essentially according to Burnette (1981). Antigen-antibody complexes were revealed using goat antibody IgG-horseradish peroxidase conjugate and 4-chloro-1-naphthol (Bio-Rad).

\section{RESULTS}

\section{Isolation of $\mathbf{H}$-protein from mitochondrial matrix}

A three-step protocol was devised to purify H-protein, which can be readily released as soluble protein from pea mitochondria

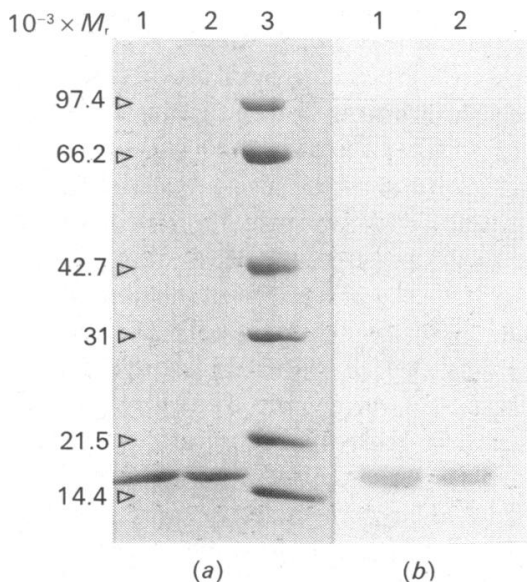

Fig. 2. Electrophoresis and immunochemical analyses of $\mathbf{H}$-protein $\left(\mathbf{H}_{1}\right.$ and $\mathrm{H}_{2}$ ) from pea leaf mitochondria

$H_{1}$ and $H_{2}$ proteins (see Fig. 1) were separated on a SDS/7.5-15\% gradient polyacrylamide slab gel at room temperature. Lane $1, \mathrm{H}_{1}-$ protein, $3 \mu \mathrm{g} ; 2, \mathrm{H}_{2}$-protein, $3 \mu \mathrm{g} ; 3$, Bio-Rad standards, $15 \mu \mathrm{g}$. (a) Polypeptides were revealed with Coomassie Brilliant Blue R-250 staining. (b) Immunostaining of polypeptides $\left(\mathrm{H}_{1}\right.$ and $\left.\mathrm{H}_{2}\right)$ using polyclonal antibody raised against $\mathrm{H}$-protein $\left(\mathrm{H}_{2}\right.$ form). The antibody-antigen complexes were revealed as described in the Materials and Methods section.
(Bourguignon et al., 1988). After the final step of purification (anion-exchange chromatography on Mono $\mathrm{Q}$ using f.p.l.c.) the native enzyme was eluted as two distinct peaks at 250 and $350 \mathrm{mM}-\mathrm{KCl}$ (Fig. 1). Each 'form' exhibited an identical $M_{\mathrm{r}}$ of 15000 on SDS/PAGE (Fig. 2) and they were not distinguishable by PAGE under non-denaturating conditions. The $N$-terminal sequence of each 'form' was determined using a gas-liquid sequencer and gave a single sequence of 20 amino acid residues (Ser-Asn-Val-Leu-Asp-Gly-Leu-Lys-Tyr-Ala-Pro-Ser-His-GluTry-Val-Lys-His-Glu-Gly) [see Macherel et al., (1990)]. Furthermore, polyclonal antibodies raised against the purified $\mathrm{H}$-protein [see Macherel et al. (1990)] reacted with both 'forms' separated by SDS/PAGE and transferred to nitrocellulose (Fig. 2). These 'forms' were not artefacts of chromatography, because rechromatography of the two separated forms on the anionexchange column gave a single peak of $\mathrm{H}$-protein at their original elution volume. Furthermore, in other experiments, the distribution of H-protein between the two peaks was not affected by the inclusion of proteinase inhibitors $(5 \mathrm{~mm}-\epsilon$-aminohexanoic acid, $1 \mathrm{~mm}$-benzamidine, $1 \mathrm{~mm}$-phenylmethanesulphonyl fluoride) in the lysis buffer or by the amount of protein loaded on to the column (not shown). Collectively, these results indicated that the occurrence of two peaks of $\mathrm{H}$-protein during anionexchange (Mono Q HR) chromatography was not an artefact of the experimental protocol. Each 'form' was assayed for $\mathrm{H}$ protein activity. Surprisingly, both 'forms' catalysed the rapid fixation of $\left[{ }^{14} \mathrm{C}\right]$ bicarbonate to the carboxy group carbon atom of glycine during the exchange reaction (Fig. 1), whereas the reversible exchange of electrons between NADH and lipoamide bound to the $\mathrm{H}$-protein was seen only with the form eluted at $350 \mathrm{~mm}-\mathrm{KCl}$ (Fig. 3).

These two forms could be a result of the synthesis of two proteins coded by distinct structural genes with their own pattern of regulation. This hypothesis, however, can be ruled out because a single-copy gene encoding the $\mathrm{H}$-protein has been detected in the pea genome by two independent groups (Kim \& Oliver, 1990; Macherel et al., 1990). The fact that the form eluted at $250 \mathrm{~mm}-$ $\mathrm{KCl}$ during anion-exchange chromatography does not react with an excess of DTNB in the presence of NADH and L-protein whereas it is still able to catalyse a carboxy $-{ }^{14} \mathrm{CO}_{2}$ exchange reaction strongly suggests that these two forms differ in the lipoyl part covalently attached to a specific lysine side chain of the $\mathrm{H}$ protein. For example, it might be expected that the methylamine bound to the lipoamide of the $\mathrm{H}$-protein (methylamine-H-protein intermediate) (Motokawa \& Kikuchi, 1974) would prevent 


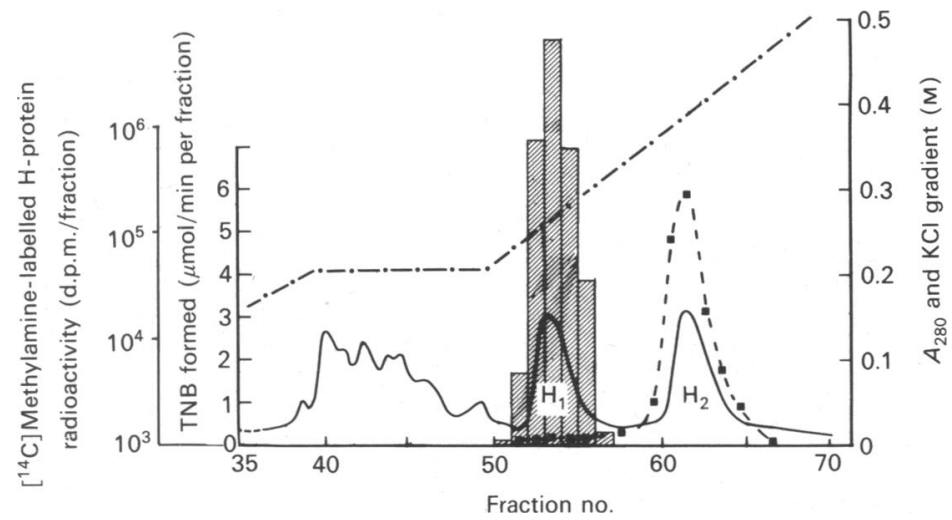

Fig. 3. Separation of H-protein from pea leaf mitochondria by chromatography on Mono $\mathbf{Q}$

The preparation of $\mathrm{H}$ protein from the matrix extract containing $2 \mathrm{~mm}-\left[2-^{14}\right]$ glycine $\left(18 \times 10^{4} \mathrm{~Bq} / \mathrm{nmol}\right)$ is described in the text. Matrix extract was fractionated by gel filtration on Sephacryl S-300 (see the Materials and Methods section) and the pooled fraction containing H-protein was applied to a Mono Q HR 10/10 column equilibrated in buffer D (see the Materials and Methods section). After sample loading the column was eluted with a gradient of $0-0.5 \mathrm{M}-\mathrm{KCl}$ in buffer D (.-.-). Fractions of $1 \mathrm{ml}$ were collected and assayed for radioactivity ( $\square,\left[{ }^{14} \mathrm{C}\right]$ methylamine-labelled $\mathrm{H}$-protein) and for DTNB-dependent $\mathrm{H}$-protein activity [TNB formed ( $\square$ ); see Scheme 2]. Note that bound radioactivity was formed exclusively in $H_{1}$ exhibiting no DTNB-dependent $\mathrm{H}$-protein activity.,$- A_{\mathbf{2 8 0}}$.

DTNB-dependent intramolecular reactions leading to the oxidized form of lipoamide. Experiments were therefore undertaken to verify this hypothesis.

\section{Characterization of $\mathbf{H}$-protein forms on ion-exchange chromatography}

If the lysis buffer (see the Experimental section) contains $1 \mathrm{~mm}$-glycine, two peaks of $\mathrm{H}$-protein activity (glycine carboxy $-{ }^{14} \mathrm{CO}_{2}$ exchange) eluted at $250 \mathrm{~mm}\left(\mathrm{H}_{1}\right)$ and $350 \mathrm{~mm}$ $\left(\mathrm{H}_{2}\right)-\mathrm{KCl}$ were observed on anion-exchange chromatography on Mono Q (Fig. 1). In contrast, in the absence of glycine, only one peak of $\mathrm{H}$-protein activity was observed (see Bourguignon et al., $1988)$ and this remaining form eluted at $350 \mathrm{~mm}-\mathrm{KCl}\left(\mathrm{H}_{2}\right)$ was capable of catalysing both the carboxy- ${ }^{14} \mathrm{CO}_{2}$ exchange reaction and the reversible exchange of electrons between NADH and bound lipoamide in the presence of DTNB. These results suggest that the peak eluted at $250 \mathrm{~mm}-\mathrm{KCl}\left(\mathrm{H}_{1}\right)$ might correspond to the methylamine- $\mathrm{H}$-protein intermediate characterized in reconstituted systems containing $\mathrm{P}$ - and $\mathrm{H}$-proteins purified from plant (Walker \& Oliver, 1986) and mammalian (Motokawa \& Kikuchi, 1974; Fujiwara et al., 1984) mitochondria. This intermediate is probably formed in the early steps of H-protein isolation when $\mathrm{P}$ - and $\mathrm{H}$-protein react together in the presence of glycine. In support of this suggestion, $\mathrm{H}_{1}$ was readily converted into $\mathrm{H}_{2}$ by incubating the former with purified $T$-protein in the presence of $\mathrm{H}_{4}$ PteGlu (not shown). Parenthetically, in agreement with Fujiwara et al. (1984), a large excess of T-protein also catalysed, but at a much lower rate, this conversion in the absence of $\mathrm{H}_{4}$ PteGlu. In addition the conversion of $\mathrm{H}_{1}$ into $\mathrm{H}_{2}$ catalysed by the T-protein led to the full recovery of DTNBdependent $\mathrm{H}$-protein activity. The methylamine- $\mathrm{H}$-protein intermediate was further characterized by including $\left[2-{ }^{14} \mathrm{C}\right]$ glycine in the lysis buffer. Under these conditions, bound radioactivity was found exclusively in $\mathrm{H}_{1}$ on anion-exchange chromatography on Mono Q (Fig. 3). Collectively, these results demonstrate that the $\mathrm{H}$-protein peaks eluted at 250 and $350 \mathrm{mM}-\mathrm{KCl}$ correspond to the methylamine- $\mathrm{H}$-protein and oxidized $\mathrm{H}$-protein respect-

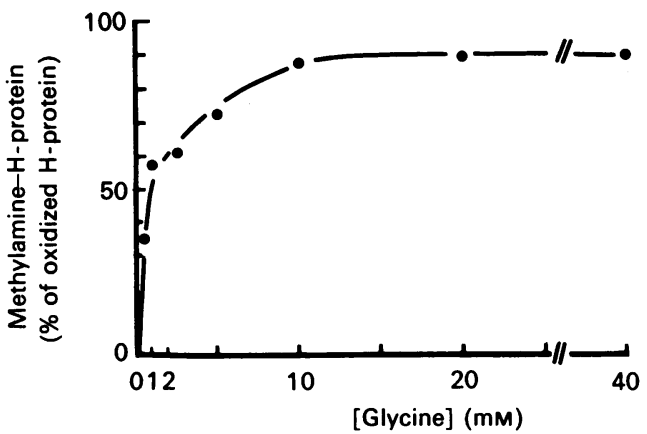

Fig. 4. Effect of increasing concentrations of glycine on the loading of H-protein with methylamine catalysed by P-protein

The extent of the loading of $\mathrm{H}$-protein with methylamine was described in the text. (The methylamine-H-protein, in contrast with the oxidized form, is unable to react with an excess of DTNB in the presence of NADH and L-protein.) The assay mixture (see the Materials and Methods section) in a final volume of $100 \mu \mathrm{l}$ contained $30 \mu \mathrm{g}$ of P-protein and $30 \mu \mathrm{g}$ of $\mathrm{H}$-protein (approximate ratio of 2 P-protein dimers:27 $\mathrm{H}$-protein monomers). Note that rather high concentrations of glycine are required to saturate the $\mathrm{H}$-protein with methylamine.

ively. These results also demonstrate that the methylamine$\mathrm{H}$-protein intermediate is rather stable because it is not degraded during all the various chromatographic steps necessary for the purification of $\mathrm{H}$-protein, including gel filtration (see Walker \& Oliver, 1986) and anion-exchange chromatography.

Since the methylamine-H-protein, in contrast with the oxidized form, is unable to react with an excess of DTNB in the presence of NADH and L-protein we have used this assay to determine indirectly the extent of the loading of $\mathrm{H}$-protein with methylamine in an assay system where $\mathrm{P}$ - and $\mathrm{H}$-protein alone jointly catalyse the loading reaction in the presence of pyridoxal phosphate and glycine.

\section{Loading of $\mathbf{H}$-protein with methylamine}

Fig. 4 shows the effect of increasing concentrations of glycine on the loading of $\mathrm{H}$-protein with methylamine catalysed by $\mathrm{P}$ protein. In this experiment the $\mathrm{P}$ - and $\mathrm{H}$-proteins were present in the assay medium at an approximate ratio of $2 \mathrm{P}$-protein dimers : $27 \mathrm{H}$-protein monomers. Such a ratio was chosen because it was previously determined for the complete glycine-cleavage complex present in the matrix space (Oliver et al., 1990). In addition the final volume of the assay system was small $(100 \mu \mathrm{l})$ in order to maintain a sufficiently high protein concentration such that both proteins remained in a fragile complex (Oliver et al., 1990). As the concentration of glycine increased in the medium, the rate of electron transfer between NADH and bound lipoamide catalysed by $\mathrm{L}$ - and $\mathrm{H}$-protein (oxidized form) decreased progressively. At glycine concentrations above $10 \mathrm{~mm}$, the DTNB-dependent $\mathrm{H}$-protein activity was almost negligible. We have verified that there was a good relationship between DTNB-dependent $\mathrm{H}$-protein activity and the percentage of oxidized $\mathrm{H}$-protein remaining in the incubation medium. In other words, the total amount of methylamine-H-protein intermediate isolated from the reaction mixture by gel filtration and anion-exchange chromatography (see the Experimental section) increased as the inhibition of $\mathrm{H}$-protein activity became stronger and stronger. In our assay conditions, the half-loading of the H-protein with methylamine was attained at a concentration of 2 mM-glycine (Fig. 4). Increasing the amount of Pprotein in the assay medium did not change the concentration of glycine necessary for the half-loading of the H-protein. However, in the absence of pyridoxal phosphate in the assay medium, the 
loading of $\mathrm{H}$-protein with methylamine was not observed. In fact this important cofactor was required to unmask the full activity of P-protein. This observation strongly suggests that pyridoxal phosphate is loosely bound to the P-protein and becomes detached from the protein during the course of its purification or storage. Interestingly Walker \& Oliver (1986) have previously observed that $\mathrm{P}$ - and $\mathrm{H}$-protein alone jointly catalyse the glycine $-{ }^{14} \mathrm{CO}_{2}$ exchange reaction only in the presence of pyridoxal phosphate. In addition the presence of a large excess (10-20 mM) of a reducing agent such as 2-mercaptoethanol in the incubation medium prevented the loading of $\mathrm{H}$-protein with methylamine. It is very likely therefore that such a reducing agent converted the oxidized form of the lipoamide bound to $\mathrm{H}$-protein (oxidized $\mathrm{H}$-protein) into its reduced form which no longer reacted with P-protein.

\section{DISCUSSION}

The results described in this paper demonstrate that during the early steps of $\mathrm{H}$-protein isolation, when $\mathrm{P}$ - and $\mathrm{H}$-protein react together in the presence of glycine, the methylamine intermediate bound to the lipoamide of the H-protein accumulates in the medium at the expense of oxidized H-protein. Under these conditions the methylamine intermediate can easily be separated from the oxidized H-protein on ion-exchange chromatography indicating that the two forms differ in their charge properties. These results demonstrate therefore that the methylamine intermediate is a rather stable structure that remains unaffected during all the chromatographic steps including anion-exchange chromatography. Interestingly several molecules that mimic the structure of the methylamine intermediate (i.e. $\mathrm{R}-\mathrm{S}-\mathrm{CH}_{2}-\mathrm{NH}_{2}$ ) have already been synthesized and appear to be rather stable (Henery-Logan \& Abdou-Sadet, 1972). The fact that the methylamine intermediate is less negatively charged than the corresponding oxidized form is rather puzzling because the $\mathrm{p} K$ of the free SH group in lipoate is very high $\left(\mathrm{p} K_{\mathrm{SH}}=10\right)$ (Jocelyn, 1972). We are forced to imagine therefore that either the amino group of the methylamine intermediate carries a positive charge interacting or not with a carboxy group present in the vicinity of the lipoate arm or the $\mathrm{H}$-protein undergoes a conformational change on methylamine binding, affecting the overall charge of the protein. In order to resolve this problem the structure of the $\mathrm{H}$-protein requires further investigation.

The data reported here also demonstrate that the methylamine bound to the lipoamide of the H-protein prevents DTNBdependent intramolecular reactions leading to the oxidized form of lipoamide but does not prevent the rapid exchange between $\left[{ }^{14} \mathrm{C}\right]$ bicarbonate and the carboxy group carbon atom of glycine. Such an observation confirms that the methylamine intermediate represents a necessary step for the glycine-bicarbonate exchange reaction back to glycine as shown previously by Fujiwara et al.
(1984). Our results also demonstrate that rather high concentrations of glycine are required to saturate the $\mathrm{H}$-protein with methylamine. Interestingly it was previously shown that glycine decarboxylase, either purified (Bourguignon et al., 1988) or present in the matrix space (Oliver et al., 1991), exhibits a relatively high $K_{\mathrm{m}}$ for glycine. We can therefore speculate that in vivo during the course of glycine oxidation a large amount of the methylamine intermediate is required to push $\mathrm{T}$-protein towards $5,10-\mathrm{CH}_{2} \mathrm{H}_{4}$ PteGlu production. However, we must bear in mind that the glycine decarboxylase complex represents a large proportion of the matrix enzymes in green leaf mitochondria (Douce \& Neuburger, 1989). This high protein concentration $(130 \mathrm{mg} / \mathrm{ml})$ influences biorecognition processes and leads to the formation of a multienzyme complex with enzymological properties that are very different from those of the dissociated form of the complex which occurs at low protein concentrations (Oliver et al., 1990).

\section{REFERENCES}

Bourguignon, J., Neuburger, M. \& Douce, R. (1988) Biochem. J. 255, 169-178

Burnette, W. N. (1981) Anal. Biochem. 112, 195-203

Chua, N. H. (1980) Methods Enzymol. 69, 434-446

Douce, R. \& Neuburger, M. (1989) Annu. Rev. Plant Physiol. Plant Mol. Biol. 40, 371-414

Douce, R., Bourguignon, J., Brouquisse, R. \& Neuburger, M. (1987) Methods Enzymol. 148, 403-415

Fujiwara, K., Okamura-Ikeda, K. \& Motokawa, Y. (1984) J. Biol. Chem. 259, $10664-10668$

Henery-Logan, K. R. \& Abdou-Sabet, S. (1972) J. Org. Chem. 38, 916-920

Hiraga, K. \& Kikuchi, G. (1980) J. Biol. Chem. 255, 11671-11676

Huennekens, F. M., Mathews, C. K. \& Schrimgeour, K. G. (1963) Methods Enzymol. 6, 802-806

Husic, D. W., Husic, H. D. \& Tolbert, N. E. (1987) CRC Crit. Rev. Plant Sci. 5, 45-100

Jocelyn, P. C. (1972) Biochemistry of the SH Group, Academic Press, London and New York

Kikuchi, G. \& Hiraga, K. (1982) Mol. Cell Biochem. 45, 137-149

Kim, Y. \& Oliver, D. J. (1990) J. Biol. Chem. 265, 848-853

Klein, S. M. \& Sagers, R. D. (1966) J. Biol. Chem. 241, 206-209

Macherel, D., Lebrun, M., Gagnon, J., Neuburger, M. \& Douce, R. (1990) Biochem. J. 268, 783-789

Motokawa, Y. \& Kikuchi, G. (1969) Arch. Biochem. Biophys. 135, 402-409

Motokawa, Y. \& Kikuchi, G. (1974) Arch. Biochem. Biophys. 164, 634-640

Neuburger, M., Bourguignon, J. \& Douce, R. (1986) FEBS Lett. 207, 18-22

Oliver, D. J., Neuburger, M., Bourguignon, J. \& Douce, R. (1990) Plant Physiol. 94, 833-839

Oliver, D. J., Neuburger, M., Bourguignon, J. \& Douce, R. (1991) Physiol. Plant., in the press

Towbin, H., Staehelin, T. \& Gordon, J. (1979) Proc. Natl. Acad. Sci. U.S.A. 76, $4350-4354$

Walker, J. L. \& Oliver, D. J. (1986) J. Biol. Chem. 261, 2214-2221 